\title{
Effect of Different Levels of Coconut Meal on Egg Production ${ }^{1}$
}

\author{
Manuel Soldevila and Manuel Rojas-Daporta ${ }^{2}$
}

\begin{abstract}
Different levels of coconut meal in laying diets were compared in three studies using intensity of lay and feed conversion as criteria for comparison. In all studies the production and efficiency of feed utilization decreased as the level of coconut meal was increased in the diet.

The best results were obtained when the level of coconut meal did not surpass approximately $20 \%$ of the diet. The practical level of coconut meal up to approximately $20 \%$ of the diet will be determined by its relative net cost.
\end{abstract}

\section{INTRODUCTION}

Soldevila et al. (3) reported that coconut meal obtained by the expeller-process may be used up to a level of $50 \%$ in practical diets for broilers. These results generally substantiated the work of Thomas and Scott (4).

Coconut meal is known to contain no toxic factors (4). The solventextracted product has proven superior to the expeller-extracted one, because the lysine present is less severly damaged (1). Coconut meal is known to be deficient in some of the essential amino acids, particularly methionine and phenylalanine (2).

The objective of these studies was to determine the maximum levels of expeller-extracted coconut meal that could be efficiently used in practical laying diets.

\section{MATERIALS AND METHODS}

Different levels of coconut meal were evaluated in three nutritional studies carried out with Leghorn hens at the Lajas Substation, in which production and feed conversion were used as criteria for comparison. The first two studies were carried out in 1966-67, and the third one in 1968-69. In the three trials individual wire cages over water pits were used.

In the first study, a partially-balanced-incomplete-block design with eight treatments and six replications was used. Each replicate consisted

${ }^{1}$ Manuscript submitted to Editorial Board August 29, 1975.

${ }^{2}$ Associate Nutritionist, Animal Husbandry Department, and former Animal Husbandman, Lajas Substation, respectively, Agricultural Experiment Station, Mayagüez Campus, University of Puerto Rico, Río Piedras, P.R. 
of two hens which were housed in adjacent wire cages. In the second study, a complete block design with five treatments replicated 12 times was used. Each replicate consisted of one hen housed in an individual wire cage. In the third study, a singular block-divisible design with eight treatments replicated six times was used. Each replicate consisted of two hens housed in two adjacent wire cages.

The basal diets used in these studies are described in table 1. Feed and water were offered free choice.

\section{RESULTS AND DISCUSSION}

In the three studies, as the level of coconut meal in the diet increased over $20 \%$, the overall performance of the birds was poorer.

TABLE 1.-Composition of the basal diets used during the laying studies

\begin{tabular}{|c|c|c|c|}
\hline Ingredient & Study 1 & Study 2 & Study 3 \\
\hline & $\%$ & $\%$ & $\%$ \\
\hline Corn, dent, no. 2 , ground & $0-76.7$ & $60.9-75.8$ & $3.5-76.0$ \\
\hline Coconut meal ${ }^{2}$ & $0-76.7$ & $0-20.0$ & $0-70.0$ \\
\hline Soybean meal & 9.0 & $6.1-9.0$ & $.0-9.1$ \\
\hline Tuna fishmeal & 6.0 & $6.1-9.0$ & $.0-9.1$ \\
\hline Meat meal with bone & 3.0 & 0 & 0 \\
\hline Dicalcium phosphate & .i) & $1.0-1.7$ & $1.0-2.5$ \\
\hline Limestone, ground & $\therefore 0$ & $\frac{1}{x} \cdot 1$ & $4.0-5.2$ \\
\hline Tallow & 0 & 0 & $0-18.0$ \\
\hline $\mathrm{NaCl}$ & .5 & .5 & .5 \\
\hline Premix $^{2}$ & .3 & .3 & .3 \\
\hline Crude protein, calculated & $15.41-24.62$ & 15.25 & 15.0 .3 \\
\hline Calcium, calculated & $2.33-2.45$ & 2.55 & 2.68 \\
\hline Phosphorus, calculated & $.52-.61$ & .61 & .90 \\
\hline
\end{tabular}

'The average percentage chemical composition of the coconut meal used was: Moisture 14.03; crude protein 22.07; fat 12.39; fiber 8.32 ; ash $6.80(\mathrm{Ca} .26$ and $\mathrm{P} .84$ ); nitrogen-free extract 36.39 .

${ }^{2}$ Contains .0009 vitamins $\mathrm{A} / \mathrm{D}_{3}(500,000 / 100,000 \mathrm{IU} / \mathrm{g}) ; .0002$ riboflavin; .0006 niacin; .0250 manganese sulfate $(75 \%) ; .2000$ terramycin ( 3 g oxytetracycline and 3 mg vitamin $B_{12} / \mathrm{kg}$ ).

In study 1 (table 2), the experimental control (commercial diet 8) was matched in overall performance only by the diets containing 0 and $13 \%$ coconut meal. A level of $26 \%$ and above of coconut meal brought about very poor results from the standpoint of feed conversion, production, and mortality.

In study 2 (table 2), when isonitrogenous diets containing levels of coconut meal as high as $20 \%$ were evaluated, the overall performance of all diets was excellent and comparable.

In study 3 (table 2), where the diets were isonitrogenous and isocaloric, the results demonstrate again that levels as high as $20 \%$ coconut meal 
TABLE 2.-Average egg production and feed utilization for laying studies conducted at the Lajas substation

\begin{tabular}{|c|c|c|c|}
\hline Diet & Coconut meal in diet & Production & Feed conversion \\
\hline Number & $\%$ & Laying rate ${ }^{1}$ & Lb feed/dozen eggs \\
\hline \multicolumn{4}{|c|}{ Study 1-From July to October 1966} \\
\hline 1 & 0 & $56.0 \mathrm{a}^{2}$ & $3.88 \mathrm{a}$ \\
\hline 2 & 13 & $52.8 \mathrm{ab}$ & $4.14 \mathrm{ab}$ \\
\hline 3 & 26 & $37.8 \mathrm{bc}$ & $5.80 \mathrm{~cd}$ \\
\hline 4 & 39 & $46.0 \mathrm{ab}$ & $5.37 \mathrm{bc}$ \\
\hline 5 & 52 & $39.2 \mathrm{bc}$ & $6.17 \mathrm{~cd}$ \\
\hline 6 & 65 & $27.8 \mathrm{c}$ & $8.62 \mathrm{~d}$ \\
\hline 7 & 77 & 11.8 & 20.79 \\
\hline 8 (Commer- & 0 & $50.8 \mathrm{ab}$ & $4.70 \mathrm{abc}$ \\
\hline \multicolumn{4}{|c|}{ Study 2-From February to July 1967} \\
\hline 1 & 0 & $72.4 \mathrm{a}$ & $3.30 \mathrm{a}$ \\
\hline 2 & 5 & $71.2 \mathrm{a}$ & $3.30 \mathrm{a}$ \\
\hline 3 & 10 & $70.8 \mathrm{a}$ & $3.55 \mathrm{a}$ \\
\hline 4 & 15 & $73.4 \mathrm{a}$ & $3.27 \mathrm{a}$ \\
\hline 5 & 20 & $70.9 \mathrm{a}$ & $3.45 \mathrm{a}$ \\
\hline \multicolumn{4}{|c|}{ Study 3-From May to August $1968^{3}$} \\
\hline 1 & 0 & $76.5 \mathrm{a}^{3}$ & $3.11 \mathrm{a}$ \\
\hline 2 & 10 & $71.0 \mathrm{a}$ & $3.36 \mathrm{ab}$ \\
\hline 3 & 20 & $71.2 \mathrm{a}$ & $3.17 \mathrm{ab}$ \\
\hline 4 & 30 & $51.9 \mathrm{~b}$ & $3.70 \mathrm{bc}$ \\
\hline 5 & 40 & $46.4 \mathrm{bc}$ & $4.14 \mathrm{~cd}$ \\
\hline 6 & 50 & $37.2 \mathrm{c}$ & $4.72 \mathrm{~d}$ \\
\hline 7 & 60 & $19.0 \mathrm{~d}$ & $8.38 \mathrm{e}$ \\
\hline 8 & 70 & $13.4 \mathrm{~d}$ & $9.23 \mathrm{f}$ \\
\hline
\end{tabular}

\footnotetext{
${ }^{1}$ Percent laid during the experimental period, based on the standard 2-oz egg.

${ }^{2}$ Means followed by the same small letter or letters are not significantly different at $\mathrm{P}=.05$ level.

${ }^{3}$ Means listed below that are followed by the same letter or letters are not significantly different at $\mathrm{P}=.01$.
}

may be successfully incorporated in practical-type laying diets. These results basically corroborate the work of Thomas et al. (4) and their conclusion that the use of coconut meal requires careful formulation in order to insure proper balance of all nutrients. On the other hand, this study shows marked differences from the previous results obtained by the author and coworkers (3) with broiler chicks.

All hens in study 3 were fed a commercial laying diet after the completion of the trial. Thirty days after such change, the average production of all groups was equivalent and comparable to the control group used throughout the experiment, demonstrating that no residual 


\section{effect was caused by prior feeding to high levels of coconut meal for prolonged periods.}

\section{RESUMEN}

En tres estudios de nutrición durante el período de postura se evaluaron diferentes niveles de harina de coco en dietas prácticas, usando la intensidad de la postura y la eficiencia en la utilización del alimento como criterios de evaluación. En términos generales, el crecimiento de las aves menguó y la utilización del alimento fue más pobre a medida que el nivel de harina de coco en la dieta se aumentó.

El uso de harina de coco en niveles hasta aproximadamente el $20 \%$ de la dieta por períodos prolongados no dejó efectos residuales perjudiciales en las gallinas que lo consumieron. La harina de coco posse un alto contenido de proteína bruta que, sin embargo, es deficiente en algunos aminoácidos esenciales y su contenido calórico es menor que el del maíz. El nivel práctico a usarse en las dietas hasta aproximadamente el 20\%, 10 determinará el costo neto de su incorporación.

\section{LITERATURE CITED}

1. Fronda, F. M., Katigbak, T. V., and Ortigas, R. Z., Solvent-process extracted copra meal versus expeller-process extracted copra meal in poultry rations, Philippine Agr. 41: 314-8, 1958.

2. Momoñgan, V. G., Castillo, L. S., Gatapia, A. R., and Resurrección, R. S., High levels of copra meal in poultry and livestock rations, I. Methionine and lysine supplementation in broiler rations, Philippine Agr. 48: 163-80, 1964.

3. Soldevila, M., Rojas-Daporta, M., and Carlo, I., Rate of gain and utilization of feed as affected by different levels of coconut meal in starting, growing and fattening diets for birds of a broiler stock and laying strains, J. Agr. Univ. P.R. 54(3): 530-40, 1970.

4. Thomas, O. A. and Scott, M. L., Coconut oil meal as a protein supplement in practical poultry diets, Poultry Sci. 41: 477-85, 1962. 